\title{
An Analysis of Prospective Teachers' Curriculum Literacy Levels in Terms of Reading and Writing
}

\author{
Serkan Aslan \\ Department of Educational Sciences, Süleyman Demirel University, Turkey
}

Copyright $\subseteq 2019$ by authors, all rights reserved. Authors agree that this article remains permanently open access under the terms of the Creative Commons Attribution License 4.0 International License

\begin{abstract}
This research aims to explore prospective teachers' curriculum literacy in terms of several variables. The research has utilized the cross-sectional survey model, which is one of the descriptive survey models. The research sample holds a total of the fourth-grade 383 prospective teachers who study at teacher training programs and who have been selected by simple random sampling method. This research has been collected through personal information form and curriculum literacy scale. Descriptive statistics and multivariate analysis of variance (MANOVA) have been used during data analysis. Research results have revealed that prospective teachers have a "high" level of views regarding curriculum literacy dimensions- reading and writing. No significant difference has been identified across reading and writing dimensions in terms of gender and department. A statistically significant difference has been determined across the dimension of reading in favour of those receiving the course; however, the dimension of writing is free from any significant difference. Based upon the research findings, various recommendations have been provided. Qualitative researches carried out in order to analyze prospective teachers' curriculum literacy in depth will contribute to the relevant literature. Comparative studies that explore teachers' and prospective teachers' curriculum literacy may be conducted.
\end{abstract}

Keywords Curriculum, Curriculum Literacy, Education, Prospective Teachers

\section{Introduction}

Today, science and technology are changing at a rapid pace. There is a great need to raise individuals who keep up with this rapid change and even give direction to change. This can only be achieved through education. Education has been playing a vital role in all fields and time since the existence of human beings. The concept of education is defined in multiple ways by various scientists. Sönmez [1] defined education as the desired changes in the behaviours generating with the interaction between physical stimulants in the brain and bio-chemical. Tyler [2] defined education as a process of changing one's behavioural patterns. Çelikkaya [3] stated that education encompasses learning and teaching activities, and it can be planned and programmed as well as unplanned and unscheduled. The planned and scheduled education has ensured the emergence of the concept of curriculum.

Curriculum is a series of learning products that allows the decision of both teacher and assessment process [4]. Marsh and Willis [5] defined curriculum as interactive experiences of students under the guidance of the school. Demirel [6] indicated that curriculum is a learning experience that is provided to the learner through activities planned at school and out of the school. Remillard [7] described curriculum as a guide including what will be taught and a comprehensive framework for the activities that teachers design and decide to implement in the classroom. Curriculum can be defined as the living mechanism, which is planned in accordance with the educational objectives and conducted individually or within a group in the school and out of the school. Curriculum has a significant place in providing societies with raising humans depending on their purposes. Curriculum is important national documents and reflects broader social values and the country's wishes [8]. Thus, it is the cornerstone of education, which is planned to raise people in line with the policies of societies [9]. Özdemir [10] noted that curriculum is an essential tool in the training of qualified individuals in all countries around the world. Having such a significant place in an educational platform, curriculum is required to be accurately understood. Therefore, it is necessary for teachers to be aware of the dimensions of the curriculum and to reveal the relationship between these dimensions. This also necessitates teachers to be curriculum literates.

Curriculum literacy is acknowledged as knowing, planning and implementation [9]. Bolat [11] emphasized that curriculum literacy in education is closely related to the knowledge of the dimensions of the program and that 
teachers enjoy certain competencies related to these dimensions. Curriculum literacy can be defined as understanding structure and characteristics of the curricula; revealing the relationship among the dimensions of the curriculum-acquisition/ target, content, learning-teaching process and assessment as well as understanding the consistency between these dimensions; determining whether these dimensions are prepared in line with the requirements of the age and whether educators are prepared considering the cultural characteristics of the curriculum.

Upon analyzing the relevant literature in Turkey, a small number of studies have been conducted regarding prospective teachers' curriculum literacy. Some of the studies related to literacy curriculum in Turkey are as follows: Erdem and Eğmir [12] analyzed the literacy levels of prospective teachers and found that teachers have high curriculum literacy levels. Pre-service teachers were found to be more successful in terms of reading dimension. In another study conducted by Aslan [9], the curriculum literacy levels of the secondary school teachers were examined and that teachers' curriculum literacy levels did not significantly differ across their gender, branch, type of graduation school, seniority. Kana, Aşçı, Kana and Elkıran [13] concluded that prospective Turkish education teachers consider themselves sufficient in terms of the basic elements of the curriculum such as content, learning-teaching processes, target and measurement and evaluation. Besides, Süral and Dedebali [14] determined that prospective social studies teachers possess a high level of curriculum literacy. These research results from the average of the teachers in the curriculum, the average size of the writing size of the reading literacy scale is higher than the obtained result.

In order for teachers to use the curriculum in teaching activities, to create an educational environment, to be successful in education-training activities, knowledge and awareness of the curriculum and terms related to it must be significant [15]. A proper understanding of the curriculum is a prerequisite for the effective implementation. Therefore, teachers with curriculum literacy skills are a major factor in improving the quality of education. Teachers who are curriculum literates will greatly affect the attainment of educational objectives. They need to acquire curriculum literacy skills in undergraduate education. In fact, Bolat [11] emphasized that curriculum literacy must be provided to the teachers during pre-service education. Prospective teachers are trained in the undergraduate courses related to the curriculum. However, they are known to receive theoretical information regarding the use of the curriculum. It is of great importance to apply the activities for developing their curriculum literacy within the courses. Upon examining the relevant literature in Turkey, a small number of studies have been published specifically on examining prospective teachers' curriculum literacy levels. The lack of in-depth research has been considered as a shortcoming by the researcher. In order for the curriculum to be implemented in a qualified manner, teachers must have curriculum literacy through pre-service training. In this respect, this study is well worth in terms of examining the literacy levels of prospective teachers depending on gender, receiving curriculum development in education course and department variables along with drawing a wider picture related to the topic.

This research aims to explore prospective teachers' curriculum literacy in terms of several variables. Thus, answers to the following questions have been sought:

1. What are the participation levels of the prospective teachers related to the curriculum literacy scale dimensions?

2. Do prospective teachers' views regarding curriculum literacy scale dimensions significantly vary across their gender?

3. Do prospective teachers' views regarding curriculum literacy scale dimensions significantly vary across taking curriculum development in education course?

4. Do prospective teachers' views regarding curriculum literacy scale dimensions significantly differ across their department?

\section{Methods}

\subsection{Research Model}

This research has employed a descriptive survey model. The descriptive survey is a research model in which attitudes, views, behaviours of a sample or the whole population, or the characteristics of participants are described [16, 376]. The research has utilized the cross-sectional survey model, which is one of the descriptive survey models. The cross-sectional survey is a type of survey collected from a group in a short period of time [17]. Cross-sectional survey model has been used in the present study as the data has been collected from the prospective teachers at one heat in a short period of time.

\subsection{Population and Sample}

The population of the research consists of prospective teachers studying at the faculty of education at a state university. The research sample holds a total of the fourth-grade 383 prospective teachers who study at teacher training programs and who have been selected by simple random sampling method. This sampling method refers to the fact that every member of a population has an equal chance of participating in the research [17]. This research has preferred a simple random sampling method since prospective teachers have an equal chance of participating in the research. The research has been conducted with the fourth-grade prospective teachers. The reason for this is that the prospective teachers have received courses related 
to instruction and that they have knowledge about the curriculum. Can [18] stated that the sample should be homogenous in order to determine whether the sample represents the population and whether it consists of 240 people if the population is 10.000 ( $5 \%$ margin of error). The sample of this research can be said to represent the population since the variables are homogeneous and the selected sample is composed of 383 people. Table 1 displays the characteristics of the prospective teachers.

Table 1. The characteristics of the participants

\begin{tabular}{|l|c|c|}
\hline Gender & $\boldsymbol{f}$ & $\mathbf{\%}$ \\
\hline Female & 278 & 72 \\
\hline Male & 105 & 28 \\
\hline Curriculum Development in Education Course \\
\hline I have & 249 & 65 \\
\hline I haven't & 134 & 35 \\
\hline Department & \multicolumn{2}{|l|}{} \\
\hline Classroom teaching & 90 & 23 \\
\hline Turkish education & 34 & 9 \\
\hline Pre-school education & 71 & 19 \\
\hline CIT & 27 & 7 \\
\hline Science teaching & 61 & 16 \\
\hline Social Studies teaching & 24 & 6 \\
\hline English teaching & 49 & 13 \\
\hline Art teaching & 27 & 7 \\
\hline Total & $\mathbf{3 8 3}$ & $\mathbf{1 0 0}$ \\
\hline
\end{tabular}

Table 1 depicts that the number of female prospective teachers are high $(72 \%)$, they have taken curriculum development in education course $(65 \%)$ and they study at the department of classroom teaching (23\%).

\subsection{Data Collection Tools}

This research has deployed two data collection tools. These are:

Personal Information Form: A form has been developed in order to determine the personal information regarding prospective teachers. The form includes questions related to the participants' gender, whether the curriculum development course in education and department.

Curriculum Literacy Scale: This research has employed Curriculum Literacy Scale developed by Bolat[11]. Exploratory and confirmatory factor analyses have been conducted during the development of the scale. The exploratory factor analysis has revealed that the tool possesses two dimensions and explains $43.05 \%$ of the total variance. Factor loads of the scale have been determined to range between .40 and .83 [11]. The analysis results have shown that the first dimension "reading" consists of 15 items, while the second "writing" includes 14 items. "Reading" dimension holds such statements as "I can distinguish the relation between the target behaviour and target dimension", I can choose appropriate content for the target", while "writing" dimension includes "I can write appropriate target according to the level of the students.", "I can analyze a measurement tool by considering the targets." The Cronbach Alpha coefficient for reading and writing dimensions have been found to be .88 and .90 , respectively. The Cronbach Alpha coefficient has been identified to be .94 for the overall scale [11]. Conformity factor analysis has also been conducted to reveal fit indexes. The analysis results have shown that the fit indexes are high [11]. The statements on the five-point Likert type consist of "Never agree", "Disagree", "Intermediate agree", "Agree", and "Completely agree", and the responses are graded with "1", "2", "3", "4", "5 points, respectively.

The researcher has required permission from the researcher who developed the scale and the scale has been used in this study. The Cronbach Alpha coefficient of the scale was examined by the researcher. The Cronbach Alpha coefficients have been determined to be .94 for the first dimension, .94 for the second and .96 for the overall scale. Fraenkel, Wallen and Hyun [17] have stated that the Cronbach Alpha coefficient of .70 and above is considered reliable. Based on this reference, the scale can be said to be reliable.

\subsection{Data Collection}

Research data was collected from teachers studying in a state university in Turkey during the fall semester of the 2018-2019 academic year. Necessary permissions were obtained before the data were collected. Data were collected from prospective teachers within the framework of volunteerism principle. It took about 20 minutes for teacher candidates to respond to items in the scale. Ethical principles were taken into consideration while collecting data.

\subsection{Data Analysis}

The research data has been analyzed through use of statistical package program. First, the study confirmed whether data provided the general requirements of the parametric tests. Besides, the Kolmogrov Smirnov test assessed whether the data distributed normally. As a result of the analyses, curriculum literacy scale did not demonstrate normal distribution $(\mathrm{K}-\mathrm{S}=.05, \mathrm{p}<.05)$. However, even small deviations from the normal can be statistically significant in the studies with a large sample. Considering the relevant literature, it is recommended that the skewness and kurtosis coefficients, histograms and Q-Q graphs be considered in order to determine whether the data demonstrates normal distribution [19, 20,21]. This research has examined skewness and kurtosis coefficients in order to determine whether normality is ensured. As a 
result of the analysis, the coefficient of skewness is -.126 , the standard deviation is .125 , the coefficient of kurtosis is -.214 and the standard deviation is .249. Based on this result, the data can be said to demonstrate normal distribution [18]. Descriptive statistics and multivariate analysis of variance (MANOVA) have been used during data analysis. Several assumptions must be tested to use MANOVA. These are the absence of extreme values [20], providing multivariate normality [22], the absence of multiple linear link between dependent variables [23], homogeneity of variance-covariance matrix [24]. The analysis results have revealed that all assumptions are met. With a view to determining the level of the items in the scale, the following score intervals have been taken into account: Strongly disagree 1.00 - 1.80, Disagree 1.81 - 2.60, Partially agree 2.61-3.40, Agree $3.41-4.20$, Strongly agree $4.21-5.00$. The effect sizes of the analyzes have also been calculated and displayed in the related tables. Green and Salkind[25] have noted that the effect size value (n2) is evaluated as small .01, .06 medium, and .14 large.

\section{Findings}

This section presents findings related to whether prospective teachers' curriculum literacy levels differ across their gender, taking curriculum development in education course, and department.

Table 2 displays the participation levels of the prospective teachers regarding curriculum literacy.

Table 2 presents that the prospective teachers have a "high" level of views regarding curriculum literacy dimensions- reading $(X=3.99)$ and writing $(X=3.94)$.

Table 3 shows the one-factor MANOVA results related to whether prospective teachers' views on reading and writing dimensions of the curriculum literacy scale differ across their gender.

One-way multiple variance analysis (MANOVA) has been conducted in order to determine the common effect of gender variable on prospective teachers' views related to reading and writing dimensions of curriculum literacy. Upon examining the assumptions of the MANOVA analysis, the homogeneity assumption of the dispersion matrix is ensured according to Box's $M$ statistic $\left(\mathrm{F}_{3-702596.794}=1.421, \mathrm{p}=.235\right)$. When MANOVA table has been examined, no significant difference has been identified across the dimensions of reading and writing in terms of gender (Wilk's $\Lambda=.998, \mathrm{~F}_{(1,381)}=.415, \mathrm{p}=.66$ ). In addition, the interaction between gender and the dimensions of curriculum literacy scale has been determined to be low [25].

Table 2. Prospective teachers' participation levels regarding curriculum literacy

\begin{tabular}{|l|l|c|c|c|c|c|c|}
\hline \multicolumn{2}{|c|}{ Variables } & N & $\bar{X}$ & sd & Max & Min & Level \\
\hline \multirow{2}{*}{ Curriculum Literacy } & Reading & 383 & 3.99 & .54 & 5.00 & 2.27 & High \\
\cline { 2 - 10 } & Writing & 383 & 3.94 & .59 & 5.00 & 2.00 & High \\
\hline
\end{tabular}

Table 3. One-factor MANOVA results regarding prospective teachers' views on curriculum literacy dimensions in terms of gender

\begin{tabular}{|c|c|c|c|c|c|c|c|c|}
\hline $\begin{array}{l}\text { Dependent } \\
\text { Variables }\end{array}$ & Gender & $\mathbf{n}$ & $\bar{X}$ & sd & df & $\mathbf{F}$ & $\mathbf{p}$ & $\eta^{2}$ \\
\hline \multirow{2}{*}{ Reading } & Female & 278 & 4.00 & .53 & \multirow{2}{*}{$1-381$} & \multirow{2}{*}{.208} & \multirow{2}{*}{.64} & \multirow{2}{*}{.00} \\
\hline & Male & 105 & 3.97 & .58 & & & & \\
\hline \multirow{2}{*}{ Writing } & Female & 278 & 3.94 & .58 & \multirow{2}{*}{$1-381$} & \multirow{2}{*}{.001} & \multirow{2}{*}{.97} & \multirow{2}{*}{.00} \\
\hline & Male & 105 & 3.94 & .62 & & & & \\
\hline
\end{tabular}

Table 4. One-factor MANOVA results regarding prospective teachers' views on curriculum literacy dimensions in terms of taking curriculum development in education course

\begin{tabular}{|c|c|c|c|c|c|c|c|c|}
\hline $\begin{array}{c}\text { Dependent } \\
\text { Variables }\end{array}$ & $\begin{array}{c}\text { The Status of Taking } \\
\text { the Course }\end{array}$ & $\mathbf{n}$ & $\bar{X}$ & sd & df & $\mathbf{F}$ & $\mathbf{p}$ & $\eta^{2}$ \\
\hline \multirow{2}{*}{ Reading } & I have & 249 & 4.03 & .55 & \multirow{2}{*}{$1-381$} & \multirow{2}{*}{1.442} & \multirow{2}{*}{$.02 *$} & \multirow{2}{*}{.01} \\
\hline & I haven't & 134 & 3.91 & .52 & & & & \\
\hline \multirow{2}{*}{ Writing } & I have & 249 & 3.98 & .61 & \multirow{2}{*}{$1-381$} & \multirow{2}{*}{.843} & \multirow{2}{*}{.12} & \multirow{2}{*}{.00} \\
\hline & I haven't & 134 & 3.88 & .56 & & & & \\
\hline
\end{tabular}

$* \mathrm{p}<.05$ 
Table 4 displays the one-factor MANOVA results related to whether prospective teachers' views on reading and writing dimensions of the curriculum literacy scale differ across taking curriculum development in education course.

One-way multiple variance analysis (MANOVA) has been conducted in order to determine the common effect of receiving curriculum development in education course variable on prospective teachers' views related to reading and writing dimensions of curriculum literacy. Upon examining the assumptions of the MANOVA analysis, the homogeneity assumption of the dispersion matrix is ensured according to Box's $\mathrm{M}$ statistic $\left(\mathrm{F}_{3-2106717.192}=.326\right.$, $\mathrm{p}=.807)$. MANOVA table reveals no significant difference across the levels of reading and writing dimensions in terms of taking curriculum development in education course (Wilk's $\left.\Lambda=.986, \mathrm{~F}_{(1,381)}=2.606, \mathrm{p}=.07\right)$. Table 3 also displays a significant difference across reading dimension in favour of those who received curriculum development course $\left(\mathrm{F}_{1-381}=1.442, \mathrm{p}<.05\right)$. In addition, the interaction between taking curriculum development in education course and the dimensions of curriculum literacy scale has been determined to below [25].

One-factor MANOVA results related to whether prospective teachers' views on reading and writing dimensions of the curriculum literacy scale differ across their departments are presented in Table 5.

One-way multiple variance analysis (MANOVA) has been conducted in order to identify the common effect of department variable on prospective teachers' views related to reading and writing dimensions of curriculum literacy. Upon examining the assumptions of the MANOVA analysis, the homogeneity assumption of the dispersion matrix is ensured according to Box's $M$ statistic $\left(\mathrm{F}_{21-132458.556}=.632, \mathrm{p}=.899\right)$. MANOVA table reveals no significant difference across the levels of reading and writing dimensions in terms of the department (Wilk's $\left.\Lambda=949, \mathrm{~F}_{(7,375)}=.1 .410, \mathrm{p}=.14\right)$. Besides, the interaction between receiving curriculum development in education course and the dimensions of curriculum literacy scale has been determined to below [25].

Table 5. One-factor MANOVA results regarding prospective teachers' views on curriculum literacy dimensions in terms of department

\begin{tabular}{|c|c|c|c|c|c|c|c|c|}
\hline Dependent Variables & Department & n & $\bar{X}$ & sd & df & $\mathbf{F}$ & $\mathbf{p}$ & $\eta^{2}$ \\
\hline \multirow{8}{*}{ Reading } & Classroom teaching & 90 & 3.93 & .50 & \multirow{8}{*}{$7-375$} & \multirow{8}{*}{1.630} & \multirow{8}{*}{.12} & \multirow{8}{*}{.03} \\
\hline & Turkish teaching & 34 & 3.96 & .60 & & & & \\
\hline & Pre-school teaching & 71 & 4.10 & .58 & & & & \\
\hline & ICT & 27 & 3.78 & .51 & & & & \\
\hline & Science Teaching & 61 & 3.98 & .54 & & & & \\
\hline & Social Sciences & 24 & 4.00 & .61 & & & & \\
\hline & English teaching & 49 & 3.96 & .49 & & & & \\
\hline & Art teaching & 27 & 4.19 & .52 & & & & \\
\hline \multirow{8}{*}{ Writing } & Classroom teaching & 90 & 3.91 & .55 & \multirow{8}{*}{$7-375$} & \multirow{8}{*}{1.659} & \multirow{8}{*}{.11} & \multirow{8}{*}{.03} \\
\hline & Turkish teaching & 34 & 3.91 & .63 & & & & \\
\hline & Pre-school teaching & 71 & 4.07 & .65 & & & & \\
\hline & ICT & 27 & 3.71 & .63 & & & & \\
\hline & Science Teaching & 61 & 3.86 & .58 & & & & \\
\hline & Social Sciences & 24 & 4.07 & .59 & & & & \\
\hline & English teaching & 49 & 3.93 & .50 & & & & \\
\hline & Art teaching & 27 & 4.08 & .61 & & & & \\
\hline
\end{tabular}




\section{Discussion, Result and Recommendations}

Research results have revealed that prospective teachers' views on the reading and writing dimensions of the curriculum literacy scale are "high". Prospective teachers' high level of views on the dimensions of the curriculum literacy scale is welcomed by the researcher, since the high level of curriculum literacy among the prospective teachers who will carry out the curriculum will facilitate the qualified implementation of the curriculum. Recognition of the curriculum, target/acquisition, content, teaching-learning process and assessment by prospective teachers will provide them for applying the curriculum effectively when they start working as a teacher. Ornstein and Hunkins[26] defined the curriculum in terms of five definitions such as a plan in reaching goals, student experiences, a system dealing with people, a field of study comprising its own foundations, and finally a subject area or content. Curriculum is a guide that determines the direction of a country's education policy, because policymakers reflect the characteristics of the manpower they want to raise in a country on the curriculum and aim to reach the targets through this structure [27]. In this regard, it is vital that prospective teachers have high curriculum literacy levels. Süral and Dedebali[14] have concluded that the participation level of the prospective social studies teachers in curriculum literacy scale is high. Similar results have emerged in the studies conducted by Erdem and Eğmir[12], Kana, Aşç, Kana and Elkıran[13]. The results of these studies support those of this research.

Research results have revealed no significant difference across the dimensions of reading and writing in terms of gender. This paves the way for the fact that gender is not an effective variable on curriculum literacy. A similar result has been found in the study conducted by Erdem and Eğmir[12]. Besides, this research has also examined whether there is a significant difference across the dimensions of curriculum literacy scale in terms of whether or not prospective teachers took the curriculum development course. A statistically significant difference has been identified across the dimension of reading in favour of those receiving the course; however, the dimension of writing is free from any difference. Based on this result, it is probable that the curriculum development course contributes to the correct reading of the curriculum by the prospective teachers. Considering the content of the curriculum development course, it includes "the basic elements of the curriculum (target, content, process, evaluation) and the relations between those elements; the classification of the objectives and their relationship with the elements of the curriculum; content regulation approaches; the determination of educational needs, curriculum development process and models; curriculum design approaches, curriculum evaluation models; curriculum literacy"[28]. This course presents information related to the elements of the curriculum. In this respect, it is unlikely that prospective teachers taking this course will have high curriculum literacy level in education. In addition, the research has analyzed whether there is a significant difference across the dimensions of curriculum literacy scale in terms of the department. In this respect, no significant difference has been identified across the dimensions of reading and writing in terms of the department. Based on this result, it may be wise to mention that department has no significant impact on curriculum literacy in education. The results found in the study conducted by Erdem and Eğmir[12] are not similar to those of the present research.

Based upon the research findings, various recommendations have been provided:

1. Various studies can be conducted to examine the literacy levels of prospective teachers in terms of different variables.

2. Qualitative researches carried out in order to analyze prospective teachers' curriculum literacy in depth will contribute to the relevant literature.

3. Comparative studies that explore teachers' and prospective teachers' curriculum literacy may be conducted.

4. Studies examining the relationship between prospective teachers' professional self-efficacy perceptions and their curriculum literacy will contribute to the related literature.

\section{REFERENCES}

[1] Sönmez, V. (2010).Program geliştirmede öğretmen el kitabı. (13 ${ }^{\text {th }}$ ed.) Ankara: An1 Yayınc1lık.

[2] Tyler, R.W. (2014). Eğitim programlarının ve ögretimin temel ilkeleri.(Çev. M.E. Rüzgar\& B. Aslan) ( $1^{\text {st }}$ ed.) Ankara: Pegem Yayıncılık.

[3] Çelikkaya, H. (2014). Ĕgitim bilimlerine giriş. ( $7^{\text {th }}$ ed.) Ankara: Nobel Yayıncılik.

[4] Posner, G.J. (2004). Analyzing the curriculum. (3 ${ }^{\text {th }}$ ed.) New York: McGraw-Hill.

[5] Marsh, C.J., \& Willis, G. (2007). Curriculum: Alternative approaches, ongoing issues. ( $4^{\text {th }}$ ed.) New Jersey: Pearson.

[6] Demirel, Ö. (2017). Eğitimde program gelişstirme. (25 ${ }^{\text {th }}$ ed.) Ankara: Pegem Yayıncılık.

[7] Remillard, J.T. (2005). Examining key concepts in research on teachers' use of mathematics curricula. Review of Educational Research, 75(2), 211-246.

[8] Stabback, P. (2016). What makes a quality curriculum? Current and Critical Issues in Curriculum and Learning, 2, $1-41$.

[9] Aslan, S. (2018).The curriculum literacy level of secondary school teachers. Unpublished master thesis. Hacettepe 
University, Ankara.

[10] Özdemir, S.M. (2012). Eğitim program kavramına ilişkin öğretmen adaylarının metaforik algıları. Kuramsal Eğitimbilim Dergisi, 5(3), 369-393.

[11] Bolat, Y. (2017). Eğitim program okuryazarlı̆̆ı kavramı ve eğitim program okuryazarlığı ölçeği. Turkish Studies, 12(18), 121-138. DOI: http://dx.doi.org/10.7827/ Turkish Studies. 12103.

[12] Erdem, C., \& Eğmir, E. (2018). Öğretmen adaylarının eğitim program okuryazarlığı düzeyleri. Afyon Kocatepe Üniversitesi Sosyal Bilimler Dergisi, 20(2), 123-138.

[13] Kana, F., Aşçı, E., Kana, H., \& Elkıran, Y.M. (2018).Türkçe öğretmeni adaylarının eğitim program okuryazarlık düzeyleri. Akademik Sosyal Araştırmalar Dergisi, 6(80), 233-245.

[14] Süral, S., \& Dedebali, N.C. (2018).Study of curriculum literacy and information literacy levels of teacher candidates in department of social sciences education. European Journal of Educational Research, 7(2), 303-317.

[15] Özkan, H.H. (2016). An analysis of teachers' opinions about their knowledge of curriculum terms awareness. Universal Journal of Educational Research, 4(7), 1601-1613.

[16] Creswell, J.W. (2012). Educational research. (4 ${ }^{\text {th }}$ ed.) Boston: Pearson.

[17] Fraenkel, J.R., Wallen, N.E., \& Hyun, H.H. (2012). How to design and evaluate research in education. ( $8^{\text {th }}$ ed.) New York: McGraw Hill.

[18] Can, A. (2018). SPSS ile bilimsel araștırma sürecinde nicel very analizi. ( $6^{\text {th }}$ ed.) Ankara: Pegem Yayıncılık.

[19] Ho, R. (2006). Handbook of univariate and multivariate data analysis and interpretation with spss. ( $1^{\text {st }} \mathrm{ed}$.) London \& New York: Chapman \& Hall.

[20] Seçer, İ. (2015). SPSS ve Lisrel ile pratik very analizi: analiz ve raporlaştırma. ( $2^{\text {nd }}$ ed.) Ankara: Anı Yayıncılık.

[21] Tuna, F. (2016).Sosyal bilimler için istatistik. ( ${ }^{\text {st }}$ ed.) Ankara: Pegem Yayınc1lı.

[22] Pallant, J. (2010). Spss survival manual: a step by step guide to data analysis using spss for windows. $\left(4^{\text {th }}\right.$ ed.) Australia: Australian Copyright.

[23] Field, A. (2013). Discovering statics using SPSS. ( $4^{\text {th }}$ ed.) London: SAGE.

[24] Tabachnick, B.G., \& Fidell, L.S. (2015).Using multivariate statistics. ( $6^{\text {th }}$ ed.) Boston: Pearson Education, Inc.

[25] Green, S.B., \& Salkind, N.J. (2013).Using SPSS for windows and macintosh: Analyzing and understanding data. $\left(8^{\text {th }} \mathrm{ed}\right)$ New Jersey: Pearson.

[26] Ornstein, A.C., \&Hunkins, F.P. (2014).Curriculum foundations, principles and issues. ( $6^{\text {th }}$ ed.) London: Pearson.

[27] Oliva, P. (2009). Developing the curriculum. ( $7^{\text {th }}$ ed.) Boston: Pearson.

[28] HEC.(2018). Fen bilgisi öğretmenliği lisans ders içerikleri. Ankara: Yüksek Öğretim Kurumu. 